\section{Economic Responses of Broccoli and Cauliflower to Water and Nitrogen in the Desert}

\author{
C.A. Sanchez, R.L. Roth, and B.R. Gardner \\ Yuma Agricultural Research Center, University of Arizona, 6425 West 8th \\ Street, Yuma, AZ 85364
}

\author{
Harry Ayer \\ Department of Agricultural and Resource Economics, University of Arizona, \\ 421 Economics Building, Tucson, AZ 85721
}

Additional index words. Brassica oleracea, economic maximum yield, irrigation, response surface

\begin{abstract}
Field studies were conducted to develop water and $\mathrm{N}$ response surface models for broccoli and cauliflower (Brassica oleracea L., Botrytis Group) produced in the low desert of the southwestern United States and to estimate profit maximizing combinations of water and $\mathbf{N}$ over a range of realistic price situations. Marketable broccoli and cauliflower yields were increased by water and $\mathrm{N}$ inputs in all experiments. Generalized response equations indicate maximum broccoli yields with $43 \mathrm{~cm}$ of water and $\mathrm{N}$ at $267 \mathrm{~kg} \cdot \mathrm{ha}^{-1}$ and maximum cauliflower yields with $65 \mathrm{~cm}$ of water and $\mathrm{N}$ at $338 \mathrm{~kg} \cdot \mathrm{ha}^{-1}$. Least-cost combinations of water and $\mathbf{N}$ changed with the costs of these inputs for yield levels below the economic maximum. However, profit maximizing $\mathbf{N}$ and water rates changed little regardless of input or crop prices investigated.
\end{abstract}

The low desert region of the southwestern United States is a major production area for cool-season vegetables during the winter months. Favorable temperatures in this region allow for production of a continuous supply of produce from November through March. Although lettuce (Lactuca sativa L.) has traditionally occupied the most acreage, the acreage of broccoli and cauliflower produced in the desert has increased by $225 \%$ during the past 10 years (Howell et al., 1993).

Vegetables produced in the low desert almost totally depend on irrigation for their water requirement. Nitrogen is the nutrient most limiting to crop production in this region. In irrigated agriculture, water management has a pronounced influence on $\mathrm{N}$ management, and an understanding of this interaction is needed for selecting $\mathrm{N}$ management practices that optimize crop yield and minimize $\mathrm{N}$ losses (Letey et al., 1983; Sanchez et al., 1994; Stark et al., 1983). Furthermore, response surfaces describing the interaction between water and $\mathrm{N}$ can be used in determining economic optimum combinations of inputs under differing price behaviors (Beverly et al., 1986).

The cost of irrigation water in the low desert can vary substantially among areas. For example, surface water in several irrigation districts adjacent to the Colorado River costs

Received for publication 26 June 1995. Accepted for publication 30 Oct. 1995. This research was supported by the Water and Power Resource Service, U.S. Dept. of the Interior. We thank G. Tritz and $\mathrm{H}$. Hernandez for their valuable technical assistance. The cost of publishing this paper was defrayed in part by the payment of page charges. Under postal regulations, this paper therefore must be hereby marked advertisement solely to indicate this fact.

HortScience, Vol. 31(2), April 1996 row. Each plot was $12 \mathrm{~m}$ long and $1.44 \mathrm{~m}$ (four rows) wide. Two replications of the design were planted with the treatments randomized differently for each replication to give a total of 26 plots, which was accomplished because the lateral contained three spray lines that ran along the 13 plots. One spray line was used for each of the two replications and the remaining spray line was used for uniform irrigation during germination and stand establishment.

Colorado River water, with an average electrical conductivity of $1.4 \mathrm{dS} \cdot \mathrm{m}^{-1}$, was used for all irrigations. Water was applied twice weekly during the crop growing period. The amount of water applied for the $100 \%$ consumptive use (CU) level in each irrigation was estimated from Erie et al. (1982). The amounts of water applied each season were recorded (see Table 2). Nitrogen applied at the $100 \%$ level each week was based on existing fertilizer recommendations for the first growing season and then modified during subsequent seasons based on tissue analysis and additional experience gained.

The amount of water applied during each irrigation was calculated from the flow rate and the time required for the irrigation system to move a known distance. The amount of water applied was controlled by the use of various-sized nozzles. Stainless steel orifice plates were used to meter the required amount of $\mathrm{NH}_{4} \mathrm{NO}_{3}$ fertilizer solution into the irrigation water of each plot.

Broccoli, 'Excalibur' in 1981 and 1982 and 'Citation' in 1983, was seeded at $0.36 \mathrm{~m}$ between rows. Planting dates were 30,14 , and 19 Sept. in 1981-83, respectively. A flat-bed culture system was used to facilitate the use of the overhead sprinkler system. At the three- to four-leaf stage, plants were thinned to a spacing of $0.3 \mathrm{~m}$ within the row to give an approximate plant population of 92,000 plants/ha. Mature broccoli heads were harvested four to six times depending on uniformity of maturity [U.S. Dept. of Agriculture (USDA), 1943].

Table 1. Water and $\mathrm{N}$ treatment combinations of central composite design used in broccoli and cauliflower field experiments, 1981-84.

Studies were conducted on a Superstition sand (Typic calciorthid, sandy, mixed, hyperthermic 95\% sand) at the Yuma Mesa Agricultural Research Center. Preliminary soil samples collected at each site and water analyses indicated adequate levels of all nutrients, except $\mathrm{N}$ and $\mathrm{P}$. Phosphorus, from triple superphosphate, was applied at $224 \mathrm{~kg} \cdot \mathrm{ha}^{-1}$ and disked into the soil before each planting. Insect and disease control measures were implemented, as needed, using practices standard for the area.

The plots were irrigated using a modified, self-moving, lateral, sprinkler irrigation system (Roth and Gardner, 1989) that applied five rates of water and five rates of $\mathrm{N}$ (solution $\mathrm{NH}_{4} \mathrm{NO}_{3}$ ) in specified combinations (see Table 1). The treatments were arranged in a central composite rotatable design (Cochran and Cox, 1960). The statistical design included a total of nine treatments (see Table 1), with the standard treatment replicated five times; this gave a total of 13 plots randomized down the crop

\begin{tabular}{lcc}
\hline \hline & $\begin{array}{c}\text { Water }^{\mathrm{z}} \\
\text { applied } \\
(\%)\end{array}$ & $\begin{array}{c}\mathrm{N}^{\mathrm{y}} \\
\text { applied } \\
(\%)\end{array}$ \\
\hline Treatment $^{\mathrm{x}}$ & 50 & 100 \\
2 & 65 & 53 \\
3 & 65 & 147 \\
4 & 100 & 33 \\
5 & 100 & 100 \\
6 & 100 & 167 \\
7 & 135 & 53 \\
8 & 135 & 147 \\
9 & 150 & 100 \\
\hline
\end{tabular}

${ }^{2}$ Water applied at the $100 \%$ level each week was estimated after Erie et al. (1982). Other treatments were applied in the proportional amounts indicated. y Nitrogen applied to the $100 \%$ level each week was based on existing fertilizer recommendations. Other treatments were applied in the proportional amounts indicated.

xThe central composite design called for treatment 5 to be replicated five times down the row to give a total of 13 plots per line. The whole treatment structure was replicated and re-randomized down two lines to give a total of 26 plots. 
Crop Production

Table 2. Bimonthly irrigation, rainfall, and $\mathrm{N}$ application for 100\% water and $\mathrm{N}$ treatments in all broccoli and cauliflower experiments from 1981 through 1984.

\begin{tabular}{|c|c|c|c|c|c|c|c|c|c|}
\hline \multirow[b]{2}{*}{ Period } & \multicolumn{3}{|c|}{ 1981-82 } & \multicolumn{3}{|c|}{ 1982-83 } & \multicolumn{3}{|c|}{ 1983-84 } \\
\hline & $\begin{array}{c}\text { Irrig. }{ }^{2} \mathrm{H}_{2} \mathrm{O} \\
\text { applied } \\
(\mathrm{cm})\end{array}$ & $\begin{array}{l}\text { Rain } \\
(\mathrm{cm})\end{array}$ & $\begin{array}{c}\mathrm{N}^{\mathrm{y}} \\
\text { applied } \\
\left(\mathrm{kg} \cdot \mathrm{ha}^{-1}\right)\end{array}$ & $\begin{array}{c}\text { Irrig. }{ }^{2} \mathrm{H}_{2} \mathrm{O} \\
\text { applied } \\
\text { (cm) }\end{array}$ & $\begin{array}{l}\text { Rain } \\
(\mathrm{cm})\end{array}$ & $\begin{array}{c}\mathrm{N}^{\mathrm{y}} \\
\text { applied } \\
\left(\mathrm{kg} \cdot \mathrm{ha}^{-1}\right)\end{array}$ & $\begin{array}{c}\text { Irrig. }{ }^{2} \mathrm{H}_{2} \mathrm{O} \\
\text { applied } \\
(\mathrm{cm})\end{array}$ & $\begin{array}{l}\text { Rain } \\
(\mathrm{cm})\end{array}$ & $\begin{array}{c}\mathrm{N}^{\mathrm{y}} \\
\text { applied } \\
\left(\mathrm{kg} \cdot \mathrm{ha}^{-1}\right)\end{array}$ \\
\hline \multicolumn{10}{|c|}{ Broccoli } \\
\hline 1-15 Sept. & --- & --- & --- & $4.29^{*}$ & 0 & 0 & --- & --- & --- \\
\hline 16-30 Sept. & $2.49^{*}$ & 0 & 0 & $5.94^{*}$ & 0 & 22.5 & $13.3^{*}$ & 0.56 & 0 \\
\hline $1-15$ Oct. & $8.51^{*}$ & 0.08 & 0 & 11.91 & 0 & 22.4 & $3.99^{*}$ & 1.12 & 21.3 \\
\hline 16-31 Oct. & 3.40 & 0 & 34.2 & 6.86 & 0 & 24.8 & 5.28 & 0 & 24.6 \\
\hline 1-15 Nov. & 3.99 & 0 & 22.3 & 4.67 & 0.06 & 51.1 & 7.34 & 0 & 55.4 \\
\hline 16-30 Nov. & 3.38 & 0.25 & 22.7 & 7.16 & 0.61 & 77.5 & 8.05 & 0.18 & 39.3 \\
\hline 1-15 Dec. & 3.58 & 0 & 59.4 & 2.34 & 4.19 & 24.5 & 5.18 & 1.40 & 38.5 \\
\hline 16-31 Dec. & 4.06 & 0 & 38.5 & 4.42 & 0.03 & 0 & 6.27 & 1.14 & 22.2 \\
\hline 1-15 Jan. & 4.04 & 0.56 & 19.4 & --- & --- & --- & 5.23 & 0.66 & 0 \\
\hline Total & 33.5 & 0.89 & 196.5 & 47.6 & 4.88 & 222.8 & 54.6 & 5.05 & 201.4 \\
\hline \multicolumn{10}{|c|}{ Cauliflower } \\
\hline 1-15 Sept. & --- & --- & --- & $4.29^{*}$ & 0 & 0 & --- & --- & --- \\
\hline 16-30 Sept. & $2.49^{*}$ & 0 & 0 & $5.94^{*}$ & 0 & 22.5 & $13.25^{*}$ & 0.56 & 0 \\
\hline $1-15$ Oct. & $8.53^{*}$ & 0.08 & 0 & 10.34 & 0 & 22.4 & $3.99^{*}$ & 1.12 & 21.3 \\
\hline 16-31 Oct. & 3.33 & 0 & 33.6 & 8.43 & 0 & 24.8 & 5.16 & 0 & 21.4 \\
\hline 1-15 Nov. & 3.81 & 0 & 22.6 & 4.67 & 0.05 & 51.1 & 7.26 & 0 & 54.8 \\
\hline 16-30 Nov. & 3.33 & 0.25 & 22.1 & 7.16 & 0.61 & 52.4 & 8.03 & 0.17 & 38.5 \\
\hline 1-15 Dec. & 3.68 & 0 & 39.6 & 1.5 & 4.19 & 49.7 & 4.37 & 1.40 & 38.5 \\
\hline 16-31 Dec. & 3.91 & 0 & 36.2 & 5.97 & 0.03 & 46.9 & 5.77 & 1.14 & 43.8 \\
\hline 1-15 Jan. & 4.62 & 0.53 & 37.1 & 4.75 & 0 & 0 & 6.48 & 0.66 & 43.6 \\
\hline 16-31 Jan. & 3.99 & 0.25 & 37.4 & 2.36 & 0.03 & 0 & 6.50 & 0 & 0 \\
\hline 1-15 Feb. & 3.38 & 0.05 & 19.2 & --- & --- & 0 & --- & --- & 0 \\
\hline Total & 41.1 & 1.2 & 248 & 55.4 & 4.9 & 270 & 60.8 & 5.1 & 262 \\
\hline
\end{tabular}

${ }^{2}$ Irrigation (Irrig.) treatments were $50 \%, 65 \%, 100 \%, 135 \%$, and $150 \%$ of these levels.

${ }^{y}$ Nitrogen fertilizer treatments were $33 \%, 53 \%, 100 \%, 147 \%$, and $167 \%$ of these levels.

*Uniform irrigation before treatments applied.

Table 3. Equation constants for yield response of broccoli and cauliflower to water and $\mathrm{N}$.

\begin{tabular}{|c|c|c|c|c|c|c|c|c|c|}
\hline \multirow{3}{*}{$\begin{array}{l}\text { Year of } \\
\text { experiment }\end{array}$} & \multirow{2}{*}{\multicolumn{7}{|c|}{ Equation constants $^{2}$}} & \multicolumn{2}{|c|}{$\begin{array}{l}\text { Required for } \\
\text { maximum yield }\end{array}$} \\
\hline & & & & & & & & \multirow{2}{*}{$\begin{array}{l}\begin{array}{l}\text { Water } \\
(\mathrm{cm})\end{array} \\
\end{array}$} & \multirow{2}{*}{$\begin{array}{c}\mathrm{N} \\
\left(\mathrm{kg} \cdot \mathrm{ha}^{-1}\right) \\
\end{array}$} \\
\hline & $\mathrm{C}_{0}$ & $\mathrm{C}_{1}$ & $\mathrm{C}_{2}$ & $\mathrm{C}_{3}$ & $\mathrm{C}_{4}$ & $\mathrm{C}_{5}$ & $R^{2}$ & & \\
\hline \multicolumn{10}{|c|}{ Broccoli } \\
\hline $1981-82$ & -2.70 & 0.49 & 0.070 & -0.0056 & -0.00015 & -0.00012 & 0.62 & 41.7 & 220 \\
\hline $1982-83$ & -9.27 & 0.56 & 0.066 & -0.0064 & -0.00011 & -0.00012 & 0.78 & 47.1 & 332 \\
\hline $1983-84$ & -16.08 & 0.55 & 0.131 & -0.0047 & -0.00025 & -0.00014 & 0.64 & 55.0 & 248 \\
\hline Overall & 4.71 & 0.06 & 0.065 & -0.0016 & -0.00015 & 0.00030 & 0.51 & 43.3 & 267 \\
\hline \multicolumn{10}{|c|}{ Cauliflower } \\
\hline $1981-82$ & -78.60 & 3.97 & 0.081 & -0.0447 & -0.00019 & 0.00064 & 0.79 & 46.5 & 295 \\
\hline $1982-83$ & -39.23 & 1.24 & 0.129 & -0.0153 & -0.00044 & 0.00266 & 0.75 & 72.7 & 369 \\
\hline 1983-84 & -18.27 & 0.63 & 0.126 & -0.0082 & -0.00033 & 0.00131 & 0.69 & 63.9 & 316 \\
\hline Overall & -13.65 & 0.62 & 0.107 & -0.0096 & -0.00031 & 0.00187 & 0.59 & 65.2 & 338 \\
\hline
\end{tabular}

${ }^{2}$ All equations follow the form: yield $\left(\mathrm{Mg} \cdot \mathrm{ha}^{-1}\right)=\mathrm{C}_{0}+\mathrm{C}_{1} \mathrm{~W}+\mathrm{C}_{2} \mathrm{~N}+\mathrm{C}_{3} \mathrm{~W}^{2}+\mathrm{C}_{4} \mathrm{~N}^{2}+\mathrm{C}_{5} \mathrm{WN}$, where $\mathrm{C}_{0}$ through $\mathrm{C}_{5}$ are constants and $\mathrm{W}=$ water $(\mathrm{cm})$ and $\mathrm{N}=$ nitrogen $\left(\mathrm{kg} \cdot \mathrm{ha}{ }^{-1}\right)$.

Table 4. Profit maximizing water and $\mathrm{N}$ rates for various input and product prices for broccoli.

\begin{tabular}{|c|c|c|c|c|c|}
\hline \multicolumn{3}{|c|}{$\begin{array}{c}\text { Price } \\
\text { situation }^{z}\end{array}$} & \multicolumn{2}{|c|}{$\begin{array}{c}\text { Profit } \\
\text { maximizing } \\
\text { inputs }\end{array}$} & \multirow{2}{*}{$\begin{array}{c}\text { Profit } \\
\text { maximizing } \\
\text { optimum yield } \\
\left(\mathrm{Mg} \cdot \mathrm{ha}^{-1}\right)\end{array}$} \\
\hline $\begin{array}{l}\text { Water } \\
(\$ / \mathrm{cm})\end{array}$ & $\begin{array}{c}\mathrm{N} \\
(\$ / \mathrm{kg})\end{array}$ & $\begin{array}{c}\text { Broccoli } \\
(\$ / \mathrm{Mg})\end{array}$ & $\begin{array}{l}\text { Water } \\
(\mathrm{cm})^{\mathrm{y}}\end{array}$ & $\begin{array}{c}\mathrm{N} \\
\left(\mathrm{kg} \cdot \mathrm{ha}^{-1}\right)\end{array}$ & \\
\hline \multirow[t]{2}{*}{0.40} & 0.4 & 600 & 42.9 & 265 & 14.6 \\
\hline & 0.8 & 600 & 42.7 & 263 & 14.6 \\
\hline \multirow[t]{2}{*}{4.00} & 0.4 & 600 & 40.8 & 263 & 14.6 \\
\hline & 0.8 & 600 & 40.9 & 263 & 14.6 \\
\hline \multirow[t]{2}{*}{0.40} & 0.4 & 1500 & 43.2 & 267 & 14.6 \\
\hline & 0.8 & 1500 & 43.1 & 266 & 14.6 \\
\hline \multirow[t]{2}{*}{4.00} & 0.4 & 1500 & 42.4 & 266 & 14.6 \\
\hline & 0.8 & 1500 & 42.3 & 265 & 14.6 \\
\hline
\end{tabular}

${ }^{2}$ These prices represent extremes encountered for low desert winter-vegetable region.

${ }^{\mathrm{y}}$ Water is priced at cost per centimeter applied over a hectare. 

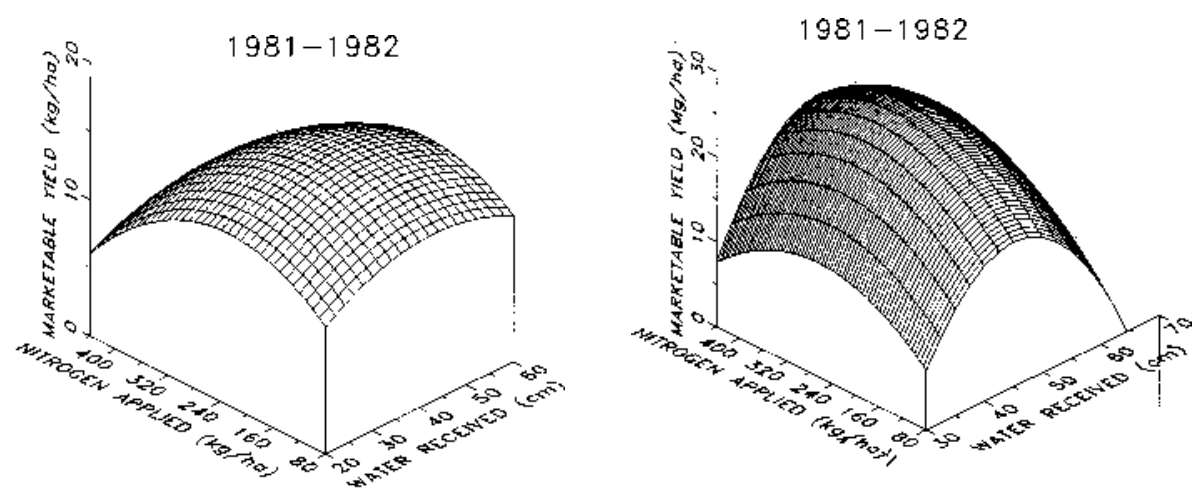

The first and last harvest dates were 3 and 14 Jan. in 1982, 10 Dec. and 13 Jan. in 1983, and 5 and 16 Jan. in 1984.

'Snowball 123' cauliflower was seeded at $0.36 \mathrm{~m}$ between rows with planting dates being the same as for broccoli. Plants were thinned at the two- to three-leaf stage to a spacing of $0.46 \mathrm{~m}$ within the row to give an approximate population of 61,000 plants/ha. Mature cauliflower was harvested from the center two rows of each plot and marketable yields were determined after grading (USDA, 1968). First and last harvest dates were $29 \mathrm{Jan}$. and 11 Feb. in 1982, 17 and 24 Jan. in 1983, and 23 Jan. and 1 Feb. in 1984. Midribs were collected from all plots beginning at the fourto six-leaf stage of growth and thereafter at $\approx 14$-day intervals until just before harvest. The midribs were dried at $65 \mathrm{C}$ for $48 \mathrm{~h}$ and ground to pass a $0.417-\mathrm{mm}$ (40-mesh) screen. Nitrate-N in the midrib tissue was determined potentiometrically (Baker and Smith, 1969). Critical nitrate-N levels for broccoli and cauliflower have been reported previously (Doerge et al., 1991; Gardner and Roth, 1989, 1990).

Crop production functions were fit to quadratic equations using SAS-REG and SASRSREG (SAS Inst., 1982). Generalized response equations for broccoli and cauliflower were calculated using the data from all three seasons. Profit-maximizing yields were calculated by setting the partial derivatives of the generalized response functions $(\mathrm{dy} / \mathrm{dW}$ and $\mathrm{dy} / \mathrm{dN}$ ) equal to the price ratios of inputs and product $\left(\mathrm{P}_{\mathrm{w}} / \mathrm{P}_{\mathrm{y}}\right.$ and $\left.\mathrm{P}_{\mathrm{n}} / \mathrm{P}_{\mathrm{y}}\right)$ and solving the equations simultaneously (Heady et al., 1955; Hexem and Heady, 1978).

\section{Results and Discussion}

Crop production. All plots received uniform irrigation during the first 3 weeks after seeding. After plant stands were established, the irrigation treatments imposed were proportional to the $100 \% \mathrm{CU}$ treatment (Table 1). Deviation from the planned irrigation treatments occurred during November through December in 1982-83 and 1983-84 when more than normal rainfall was received (Table 2). Cumulative $\mathrm{N}$ fertilization treatments were

Table 5. Profit maximizing water and $\mathrm{N}$ rates for various input and product prices for cauliflower.

\begin{tabular}{|c|c|c|c|c|c|}
\hline \multicolumn{3}{|c|}{$\begin{array}{c}\text { Price } \\
\text { situation }^{2}\end{array}$} & \multicolumn{2}{|c|}{$\begin{array}{c}\text { Profit } \\
\text { maximizing } \\
\text { inputs } \\
\end{array}$} & \multirow{2}{*}{$\begin{array}{c}\text { Profit } \\
\text { maximizing } \\
\text { optimum yield } \\
\left(\mathrm{Mg} \cdot \mathrm{ha}^{-1}\right)\end{array}$} \\
\hline $\begin{array}{l}\text { Water } \\
(\$ / \mathrm{cm})\end{array}$ & $\begin{array}{c}\mathrm{N} \\
(\$ / \mathrm{kg})\end{array}$ & $\begin{array}{c}\text { Broccoli } \\
(\$ / \mathrm{Mg})\end{array}$ & $\begin{array}{l}\text { Water } \\
(\mathrm{cm})^{\mathrm{y}}\end{array}$ & $\begin{array}{c}\mathrm{N} \\
\left(\mathrm{kg} \cdot \mathrm{ha}^{-1}\right)\end{array}$ & \\
\hline \multirow[t]{2}{*}{0.40} & 0.4 & 500 & 65.2 & 336 & 24.8 \\
\hline & 0.8 & 500 & 65.0 & 334 & 24.8 \\
\hline \multirow[t]{2}{*}{4.00} & 0.4 & 500 & 64.7 & 334 & 24.8 \\
\hline & 0.8 & 500 & 64.5 & 333 & 24.8 \\
\hline \multirow[t]{2}{*}{0.40} & 0.4 & 2000 & 65.3 & 337 & 24.8 \\
\hline & 0.8 & 2000 & 65.3 & 337 & 24.8 \\
\hline \multirow[t]{2}{*}{4.00} & 0.4 & 2000 & 65.2 & 337 & 24.8 \\
\hline & 0.8 & 2000 & 65.2 & 336 & 24.8 \\
\hline
\end{tabular}

${ }^{2}$ These prices represent extremes encountered for low desert winter-vegetable region.

${ }^{\mathrm{y}}$ Water is priced at cost per centimeter applied over a hectare. 


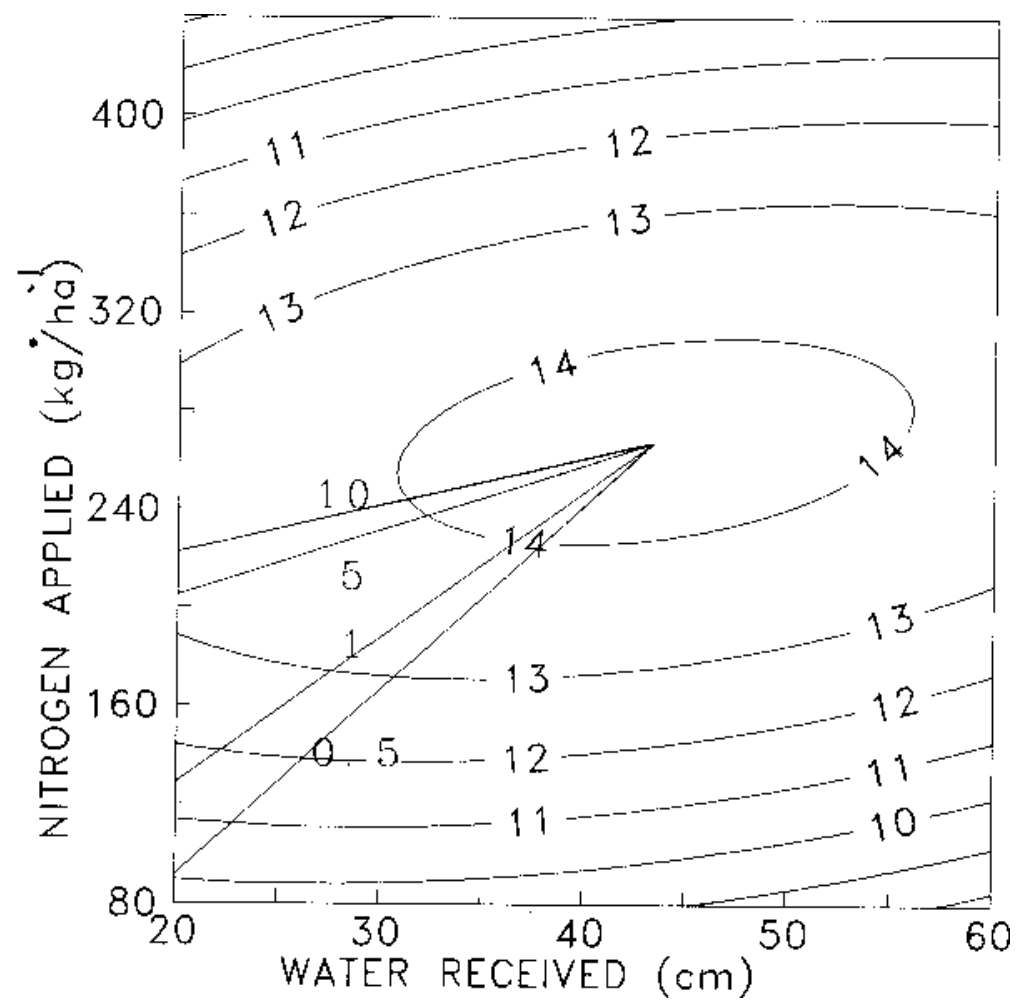

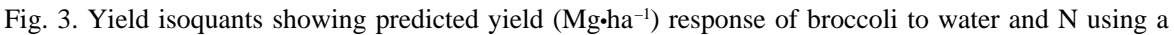
generalized equation from data for all three years. Straight lines are isoclines showing substitution rates between inputs at various price ratios $\left(\mathrm{P}_{\mathrm{w}} / \mathrm{P}_{\mathrm{n}}=10,5,1\right.$, and 0.5$)$.

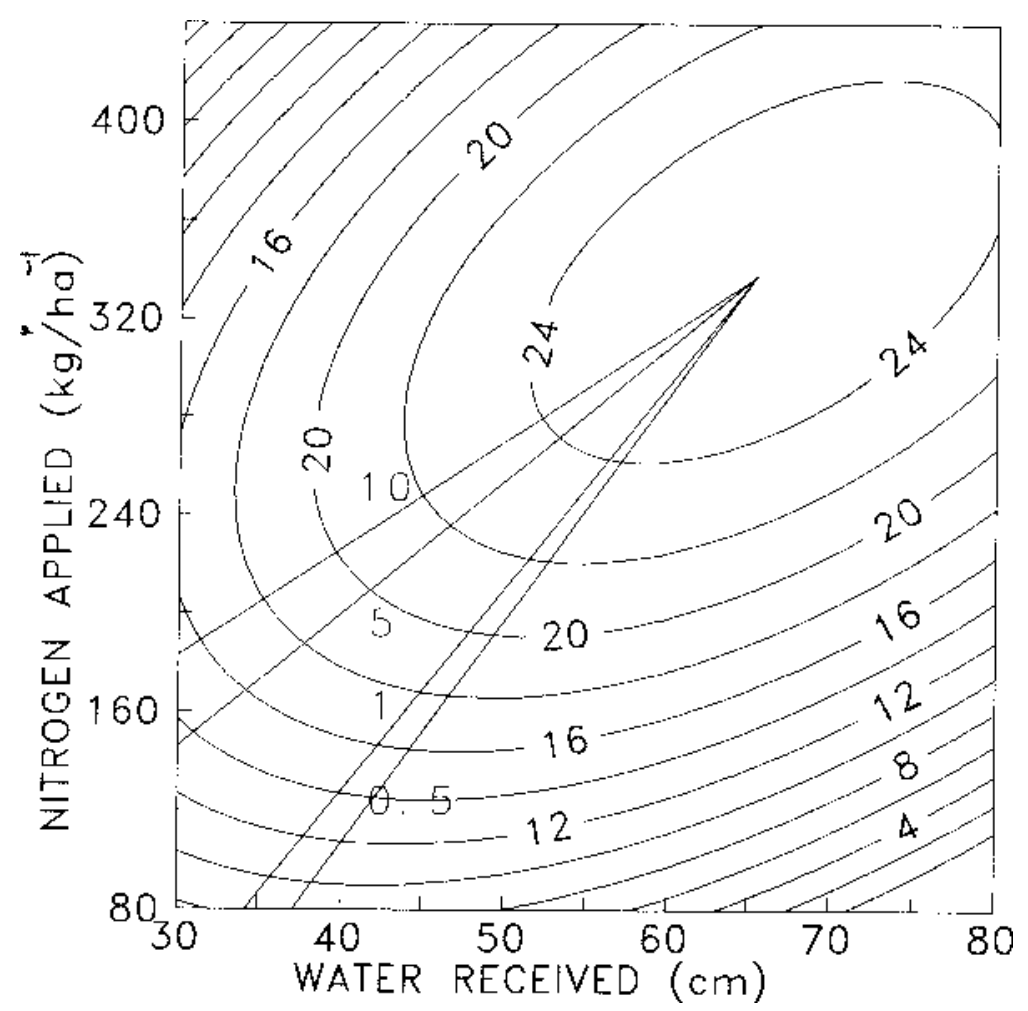

Fig. 4. Yield isoquants showing predicted yield $\left(\mathrm{Mg} \cdot \mathrm{ha}^{-1}\right)$ of cauliflower to water and $\mathrm{N}$ using a generalized equation from data for all three years. Straight lines are isoclines showing substitution rates between inputs at various price ratios $\left(\mathrm{P}_{\mathrm{w}} / \mathrm{P}_{\mathrm{n}}=10,5,1\right.$, and 0.5$)$. proportional to the $100 \%$ level in each experiment (Tables 1 and 2). Marketable broccoli and cauliflower yields were increased quadratically by water and $\mathrm{N}$ in all experiments (Figs. 1 and 2).

Maximum broccoli yields ranged from 10.8

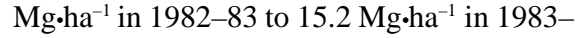
84 (Fig. 1). Rates of water required for maximum yield ranged from 42 to $55 \mathrm{~cm}$ and rates of $\mathrm{N}$ required for maximum yield ranged from 221 to $332 \mathrm{~kg} \cdot \mathrm{ha}^{-1}$ (Table 3). The generalized response surface using the combined data from all 3 years indicates that $43 \mathrm{~cm}$ of water and $\mathrm{N}$ at $267 \mathrm{~kg} \cdot \mathrm{ha}^{-1}$ are required for maximum broccoli yield of $14.6 \mathrm{Mg}$ ha $^{-1}$ (Fig. 3 and Table 3). Total water required in this experiment included water used for germination and stand establishment, while the estimates of Erie et al. (1982) do not. Therefore, under the conditions of these experiments, less water was required for broccoli production than the 50 cm estimated by Erie et al. (1982) when germination water is excluded. However, the $\mathrm{N}$ required for maximum yield exceeded rates required on loam and clay loam soils of the river valleys that are often used for vegetable production (Doerge et al., 1991). Rates of N required on the finer-textured soils seldom exceed $200 \mathrm{~kg} \cdot \mathrm{ha}^{-1}$.

Maximum cauliflower yields ranged from

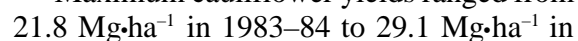
1982-83 (Fig. 2). Ranges of water and N required for maximum yield were 47 to $73 \mathrm{~cm}$

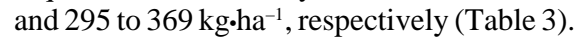
The generalized response predicts $65 \mathrm{~cm}$ of water and $\mathrm{N}$ at $338 \mathrm{~kg} \cdot \mathrm{ha}^{-1}$ to achieve a maximum yield of $24.8 \mathrm{Mg} \cdot \mathrm{ha}^{-1}$ (Fig. 4 and Table $3)$. Excluding the water required for germination and stand establishment, water consumptive use during the growing season was close to the $47 \mathrm{~cm}$ estimated by Erie et al. (1982). As with broccoli, rates of $\mathrm{N}$ required for maximum cauliflower yield exceed those typically required on finer-textured soils in the river valleys (Doerge et al., 1991).

The highest amounts of water reduced marketable yield for both crops. While there are several ways excess water can reduce yields, the major effect on this coarse-textured soil was probably leaching of $\mathrm{N}$ below the rooting zone. This conclusion is supported by midrib analysis that showed that nitrate-N values for broccoli and cauliflower were below critical levels at the $150 \%$ CU level (Figs. 5 and 6). This result explains the seemingly higher rates of $\mathrm{N}$ required on this coarse-textured soil compared to finer-textured valley soils.

Economic implications. The generalized equations can be used for calculating leastcost combinations of water and $\mathrm{N}$ to achieve specified yields. Isoclines, which are lines denoting economic substitution rates between inputs, were calculated for specified price ratios from the relationship $d W / d N=P_{n} / P_{w}$, where $P_{w}$ and $P_{n}$ are prices for water and $N$, respectively (Figs. 3 and 4). For example, when water costs are $\$ 0.40$ per cm-ha and $\mathrm{N}$ costs are $\$ 0.40$ per $\mathrm{kg}$ (price ratio of 1 or when $1 \mathrm{~cm}$-ha of water is of equal value to $1 \mathrm{~kg} \mathrm{~N}$ ), it takes $31 \mathrm{~cm}$ of water and $\mathrm{N}$ at $175 \mathrm{~kg} \cdot \mathrm{ha}^{-1}$ to achieve a broccoli yield of $13 \mathrm{Mg} \cdot \mathrm{Ma}^{-1}$ (Fig. 3). 


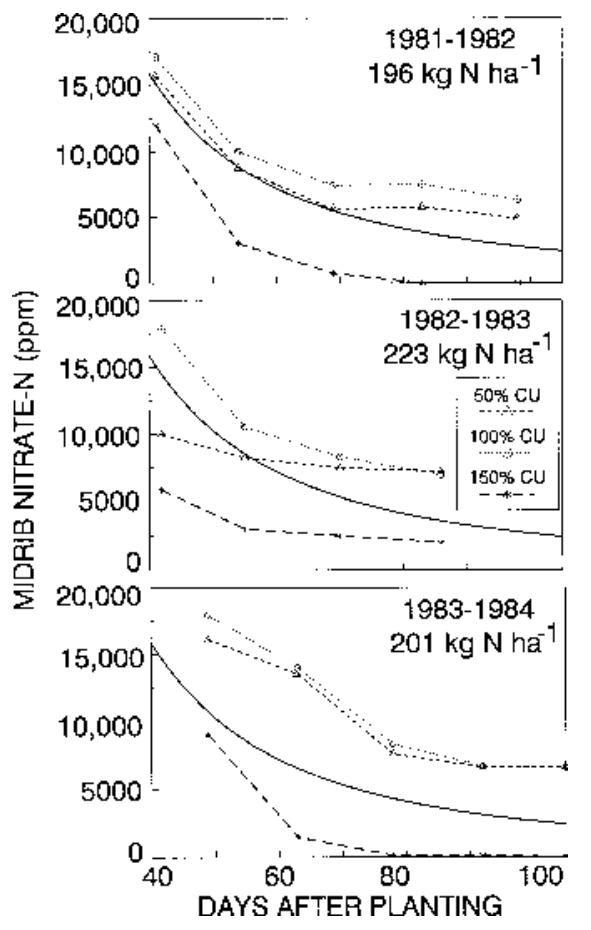

Fig. 5. Midrib $\mathrm{NO}_{3}-\mathrm{N}$ concentrations for broccoli at three irrigation levels compared to critical concentration. Solid line shows critical concentrations (CL).

However, when water costs go up to $\$ 4.00$ per ha- $\mathrm{cm}$ (price ratio of 10 or $1 \mathrm{~cm}$-ha of water is of equal value to $10 \mathrm{~kg} \mathrm{~N}$ ), the least-cost combination for a $13-\mathrm{Mg} \cdot \mathrm{ha}^{-1}$ yield becomes $\mathrm{N}$ at $220 \mathrm{~kg} \cdot \mathrm{ha}^{-1}$ and $<20 \mathrm{~cm}$ of water. Similarly, for cauliflower, the least-cost combination is $47 \mathrm{~cm}$ of water and $\mathrm{N}$ at $200 \mathrm{~kg} \cdot \mathrm{ha}^{-1}$ for a yield of $20 \mathrm{Mg} \cdot \mathrm{ha}^{-1}$ when the price ratio is 1 , but becomes $40 \mathrm{~cm}$ of water and $\mathrm{N}$ at 225 $\mathrm{kg} \cdot \mathrm{ha}^{-1}$ when the price ratio is 10 (Fig. 4).

The sale price of broccoli often varies 2 fold and the price of cauliflower 4-fold within a given production season. We were interested in calculating the profit maximizing rates of water and $\mathrm{N}$ over the range of realistic water, $\mathrm{N}$, and crop prices (Tables 4 and 5). Interestingly, the amounts of water and $\mathrm{N}$ required to

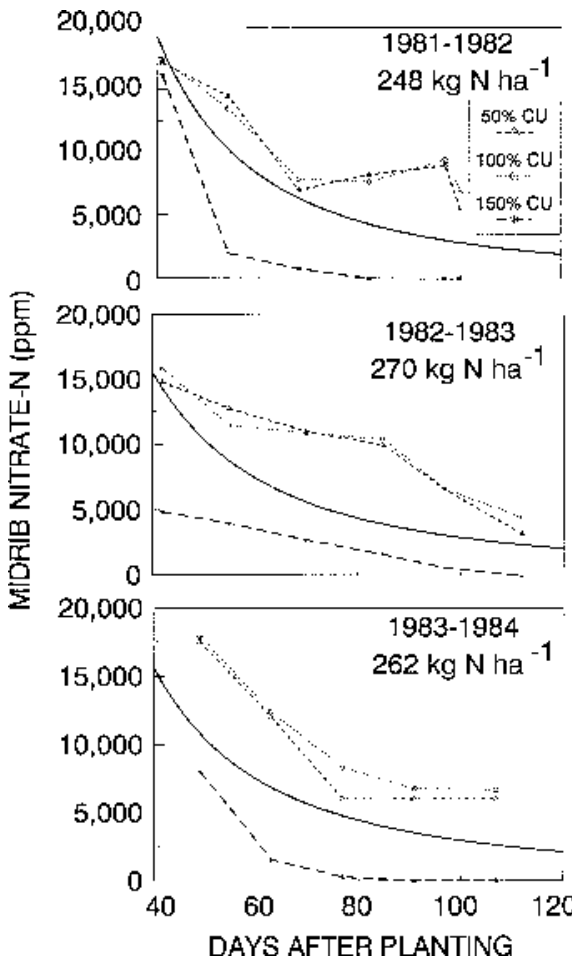

Fig. 6. Midrib $\mathrm{NO}_{3}-\mathrm{N}$ concentrations for cauliflower at three irrigation levels compared to critical concentration. Solid line shows critical concentrations (CL).

maximize profits changed little over the wide range of prices considered. Water application for profit maximizing yield varied $<3 \mathrm{~cm}$ for broccoli and $<1 \mathrm{~cm}$ for cauliflower. The variation in $\mathrm{N}$ rates was $<3 \mathrm{~kg} \cdot \mathrm{ha}^{-1}$ for broccoli and cauliflower. This small variation in water and $\mathrm{N}$ rates for profit maximizing yield across a broad price range for inputs and product is because economic optimal yields were close to maximum yields ( $>99 \%$ ), which is predicted by a unique combination of water and $\mathrm{N}$ with the model used.

\section{Literature Cited}

Baker, A.S. and R. Smith. 1969. Extracting solution for potentiometric determination of nitrate in plant tissue. J. Agr. Food Chem. 17:1284-1287. Beverly, R.B., W.M. Jarrell, and J. Letey, Jr. 1986. A nitrogen and water response surface model for sprinkler irrigated broccoli. Agron. J. 78:91-94.

Cochran, W.G. and G.M. Cox. 1960. Experimental designs. Wiley, New York. p. 346.

Doerge, T.A., R.L. Roth, and B.R. Gardner. 1991. Nitrogen fertilizer management in Arizona. College of Agr., Univ. of Arizona, Tucson Publ. 191025.

Erie, L.J., O.F. French, and K. Harris. 1982. Consumptive use of water by crops in Arizona. Univ. of Arizona Tech. Bul. 169.

Gardner, B.R. and R.L. Roth. 1989. Midrib nitrate concentration as a means for determining nitrogen needs of broccoli. J. Plant Nutr. 12:111125.

Gardner, B.R. and R.L. Roth. 1990. Midrib nitrate concentration as a means for determining nitrogen needs of cauliflower. J. Plant Nutr. 13:14351451.

Heady, E.O., J.T. Pesek, and W.G. Brown. 1955. Crop response surfaces and economic optima in fertilizer use. Iowa State Univ. Agr. Expt. Sta. Bul. 424.

Hexem, R.W. and E.O. Heady. 1978. Water production functions for irrigated agriculture. Iowa State Univ. Press, Ames.

Howell, D.R., M.A. Wilcox, and B. Tickes. 1993. Yuma County agricultural statistics report. p. 12.

Letey, J., W.M. Jarrell, N. Valoras, and R. Beverly. 1983. Fertilizer application and irrigation management of broccoli production and fertilizer use efficiency. Agron. J. 75:502-507.

Roth, R.L. and B.R. Gardner. 1989. Modified self moving irrigation system for water nitrogen crop production studies. Appl. Eng. Agr. 5:175179.

Sanchez, C.A., R.L. Roth, and B.R. Gardner. 1994. Irrigation and nitrogen management for sprinkler-irrigated cabbage on sand. J. Amer. Soc. Hort. Sci. 119:427-433.

SAS Institute. 1982. SAS user's guide: Statistics. SAS Inst., Cary, N.C.

Stark, J.C., W.M. Jarrell, and J. Letey. 1983. Evaluation of irrigation-nitrogen management practices for celery using continuous-variable irrigation. Soil Sci. Soc. Amer. J. 47:95-98.

U.S. Dept. of Agriculture. 1943. Standards for grades of bunched sprouting broccoli. U.S. Dept. Agr., Washington, D.C.

U.S. Dept. of Agriculture. 1968. Standards for grades of cauliflower. U.S. Dept. Agr., Washington, D.C. 